\title{
The economic value of the museum of central Finland
}

\author{
TIMO TOHMO*
}

\begin{abstract}
In this article, the limits of the social existence of one museum - the $M u$ seum of Central Finland - is studied from an economic point of view by asking visitors and non-visitors to museums how much they are willing to pay as taxpayers for the services of the museum. The theme is from the author's article dissertation in economics, "Regional Economic Structures in Finland: Analyses of Location and Regional Economic Impact", which he defended on 3rd August 2007 at the University of Jyväskylä.
\end{abstract}

Key words: Contingent valuation (CV) method, cost structure, monetary value (economic importance), regional economic impact, willingness-to-pay.

\section{INTRODUCTION}

Museums are perceived as major repositories of the educational and cultural value of a country's stock of objects and specimens (Johnson and Thomas, 1998). Heilbrun and Grey (2007) argue that, in essence, museums are collections of objects that reflect and pass on a cultural heritage over time. As they see it, art museums store and present the artistic elements of the cultural heritage. The generally accepted definition of a museum is an institution that serves to collect, conserve, research, interpret and exhibit a society's material culture (ICOM, 1986; Tufts and Milne, 1999). These functions could be broken down into three components: 1) preservation, 2) research and 3) communication (see e.g. Frey and Meir, 2008).
Although, according to the definition given above, the value of a museum should be measured in terms of culture and heritage, culture (and museums) is more often connected with tourism and economics. ${ }^{1}$ Moreover, culture and museums are being increasingly integrated into regional economic development systems (Tufts and Milne, 1999; Vaughan and Booth, 1989). ${ }^{2}$ As a consequence, culture and museums are increasingly linked with tourism and thus assume an important and growing role in attracting visitors. However, besides promoting tourism, an even more important task of cultural services is to enrich the life of the local inhabitants. All in all, museums are very significant institutions with multiple agendas. Heilbrun and Gray (2007) argue that all museums face the persistent question of how to allocate scarce resources among 
124 their many functions. The main question for museums is: "How is all this to be paid for?"

In the present author's thesis (Tohmo, 2007), it was argued that the economic research on culture has been strongly devoted to studies concerned with the legitimacy of public support for the arts. The outcome tends to be a debate on whether culture ought to be supported or not. Answers to the questions "How much support?" and "For which cultural objects?" and "When?" are not generally given. Khakee (1994) states that the amount of support can be estimated, not only through the income and efficiency demands laid down for cultural activities, but also on the basis of people's willingness to pay for them.

The purpose of the author's thesis (Tohmo, 2007) was to clarify the willingness of local residents aged $18+$ to pay to maintain the $\mathrm{Mu}$ seum of Central Finland, and the factors which affect that willingness. Willingness-topay was analysed with the CV method. The first aim in the study was to determine the economic value of the Museum of Central Finland. In order to find out the value of the museum, the inhabitants of Jyväskylä were asked how willing they would be to pay to keep the museum in existence. The second aim of the study was to identify - by means of a prognostic model - the factors involved in people's reported willingness-to-pay to maintain the museum. The factors characterizing high bids and the low bids, respectively, were also analysed. Finally, the difference between users (visitors) and non-users was analysed in detail.

The study sought to resolve questions that thus far had been left unasked in the literature on cultural problems in Finland. Neither the value of museums nor that of cultural goods in general had been analysed previously, not to mention applications of the contingent va- luation method to studying the factors involved in the willingness-to-pay to maintain cultural goods.

We now take a closer look at the different types of social demand for museums, namely the monetary value (the economic importance) produced by Finnish museums and externalities based on non-user benefits (the economic value) of the Museum of Central Finland.

\section{THE ECONOMIC IMPORTANCE OF FINNISH MUSEUMS}

In this chapter, Finnish museums are seen as an economic unit. We analyse the relationship between the input (man-years) and output (revenues) of museums (compare Frey and Meier, 2008). Input and output structures affect the cost functions of museums. Usually, the demand and supply for museum services are considered. The private demand for museums can be split into two categories: 1) leisure time activity and 2) visits by specialists. Frey and Meier (2008) argue that there are three major determinants relating to costs or prices (and to private demand): 1) the admission fee, 2) the opportunity cost of time and 3) the price of alternative activities. Studies have found rather low price elasticities (if anything, price inelasticities). Low price elasticities can be evidenced in support of those who advocate an increasing role overall for admission fees. Alternatively, there are those who argue that admission fees should not be charged at all (O'Hagan, 1995 and Goudriaan and van't Eind, 1985 discuss the question of introducing admission fees in museums). The opportunity cost of time is related to the time spent travelling to a museum as well as time spent in the museum. Also, the use of the ot- 
her cultural activities or going out to a restaurant are related to the private demand for a museum. Frey and Meier (2008) argue that the other type of demand for museums is social demand, which is based on external effects (non-user benefits) and effects on economic activity (jobs and revenues create multiplier effects in the economy).

The cost structures of museums differ from those of other organisations, including - according to Frey and Meier (2008) - those of other firms in the service sector. Firstly, museums operate with high fixed costs. Secondly, the marginal cost of an extra visitor is nearly zero. Thirdly, museums face cost disease, as do most other cultural organisations. Fourthly, the opportunity cost of keeping an artwork is the return that would be earned by its alternative use. Museum collections are very often very valuable and the money spent on artefacts could have been put to profitable use elsewhere.

\section{FULL-TIME MUSEUMS IN FINLAND IN 1996 AND 2006}

Museums can be classified according to various criteria such as 1) content, 2) size, 3) age and 4) institutional form (Frey and Meier, 2008). In Finland in 1996 (excluding Ahvenanmaa), 139 full-time vocational museums accounted for 280 museum targets. Of these, 137 were cultural-historical museums, 71 were specialist museums, 55 were museums of art

Table 1. Finnish museums operating full-time in 1996 and 2006.

\begin{tabular}{|c|c|c|c|c|c|c|}
\hline Type of museum & $\begin{array}{c}\text { Man-years } \\
1996\end{array}$ & $\begin{array}{c}\text { Costs } \\
\$ \\
1996\end{array}$ & $\begin{array}{l}\text { Wages } \\
\$ \\
1996\end{array}$ & $\begin{array}{c}\text { State subsidies } \\
\$ \\
1996\end{array}$ & $\begin{array}{c}\text { Municipalities } \\
\$ \\
1996\end{array}$ & $\begin{array}{c}\text { Visitors } \\
\mathrm{N} \\
1996\end{array}$ \\
\hline $\begin{array}{l}\text { State-subsidized } \\
\text { museums }(\mathrm{n}=110)\end{array}$ & 1.112 & 57.480 .898 & 26.605 .559 & 13.414 .081 & 32.193 .223 & 2.617 .447 \\
\hline $\begin{array}{l}\text { Other museums } \\
(\mathrm{n}=29)\end{array}$ & 418 & 21.022 .843 & 11.214 .747 & - & 747.703 & 1.280 .694 \\
\hline Average & 11 & 573.020 & 276.429 & 121.946 & 296.765 & 14.279 \\
\hline Type of museum & $\begin{array}{c}\text { Man-years } \\
2006\end{array}$ & $\begin{array}{c}\text { Costs } \\
\$ \\
2006\end{array}$ & $\begin{array}{l}\text { Wages } \\
\$ \\
2006\end{array}$ & $\begin{array}{c}\text { State subsidies } \\
\$ \\
2006\end{array}$ & $\begin{array}{c}\text { Municipalities } \\
\$ \\
2006\end{array}$ & $\begin{array}{c}\text { Visitors } \\
\text { N } \\
2006\end{array}$ \\
\hline $\begin{array}{l}\text { State-subsidized } \\
\text { museums }(\mathrm{n}=135)\end{array}$ & 1.559 & 115.321 .334 & 56.157 .403 & 18.720 .492 & 57.413 .442 & 3.321 .759 \\
\hline $\begin{array}{l}\text { Other museums } \\
(\mathrm{n}=28)\end{array}$ & 679 & 49.427 .903 & 23.456 .097 & - & 1.633 .836 & 1.206 .071 \\
\hline Average & 14 & 1.010 .732 & 488.426 & 138.970 & 447.328 & 14.797 \\
\hline
\end{tabular}


126 and 17 were natural science museums. There were 20 provincial museums and 16 regional museums of art. Two-thirds of all museums are maintained by municipalities, one-fifth by foundations and associations (private) and 12 per cent by the nation (Museum statistics, 1996).

In 1996, the costs of all the Finnish museums (state-subsidized) together amounted to about $\$ 57.5$ million. Nearly one-half of these costs consisted of salaries, one-fourth of real estate costs, and acquisitions accounted for about three per cent ( $\$ 2.2$ million). Onefourth of expenditure went on the care of collections, exhibitions, research activities and publishing activity. The state financed about one-fourth and the municipalities financed over one-half ( 56 per cent) of the total costs. About 13 per cent of costs were financed independently by the museums. Income from sponsors amounted altogether to about $\$ 0.6$ million. In 1996, the state subsidised $110 \mathrm{mu}-$ seums, including the Museum of Central Finland. The calculation of the state subsidy has been turned into man-years. In 1996, 1530 regular workers altogether (11 workers on average) were employed by museums. The provincial museums and regional museums of art employed an average of 14 regular workers.

In Finland (excluding Ahvenanmaa) in 2006, 163 vocational museums accounted for 322 museum targets, and were operating fulltime (table 1$)$. Nearly half of these $(n=156)$ were cultural history museums, and 85 were specialized museums of which 63 were museums of art and 18 were natural history museums (Museum statistics, 2006).

The total costs of Finnish museums (statesubsidized) in 2006 were altogether about $\$ 115$ million. Nearly one-half of these costs were staff costs, one-fourth were real estate costs and acquisitions account for about two per cent ( $\$ 2.4$ million) of costs. Other costs (care of museum collections, exhibitions, research activities and publishing activity) made up the remaining fifth.

Of the total costs of museum activities in 2006, municipalities financed about one-half and government subsidies covered about onefourth. About 17 per cent of the costs were met from independent sources. Admission fees accounted for only 6 per cent $(\$ 6.9$ million) of total revenue. Low admission fees (or free entrance) encourage everyone to visit museums and participate in cultural events (compare Goudriaan and van't Eind (1985) for the museums in Rotterdam).

\section{Museum VISITS}

In 1996, the Finnish state-subsidized museums received nearly 3.9 million visits, 14 per cent of which were by schools or student groups. The average was 14279 visits per museum. About 41 per cent of these museums had less than 5000 visits per year. Nearly onefifth of the museums had 5 001-10 000 and nearly one-fourth had 10 001-20 000 visits annually. Seven per cent of the museums had more than 40000 visits. Only four museums had more than 100000 visits; these being the Finnish National Gallery, the Post Museum, Turku Castle and the Castle of St. Olaf. The share of visits of the provincial museums and regional museums of art was 38 per cent, that of the local museums 36 per cent and that of the national museums 21 per cent.

In 2006, the Finnish museums (state-subsidized) received nearly 4.5 million visits, of which 11 per cent were by school or student groups. This averages out as 14797 visits per museum. The share of the provincial mu- 
seums and regional museums of art of all visits was 35 per cent and that of the national museums 20 per cent.

\section{The Museum of Central Finland}

The Museum of Central Finland is a museum of cultural history. It was opened to the public in 1932. The museum acts as Jyväskylä town museum and as the provincial museum for Central Finland. It records, documents and presents Central Finland's cultural history, all the way from prehistoric times up to the present. In 2006, the costs of the Museum of Central Finland amounted to $\$ 1.2$ million, of which salaries made up about $\$ 680000$ and real estate about $\$ 415000$ (table 2). The museum received nearly $\$ 708000$ from the local authority budget and $\$ 364000$ from national taxation. The museum's own proceeds amounted to about $\$ 114000$, of which $\$ 11$ 000 came from entrance tickets. The total number of visits to the Museum of Central Finland amounted to 20673 in 2006. Most of these were free entrance.

Over the course of 30 years, the Museum of
Central Finland has expanded its activities, and currently employs 20 museum workers on a full time basis. In the 1970s and 1980s, the costs were wholly met by the local authority. Although the financial contribution of the state to the Museum of Central Finland increased during the 1990s and 2000s, the local authority continued to play an important role in the expansion of the museum. Unfortunately, at the same time as resources directed at the museum grew, the number of visitors underwent a steep decline. This prompts the questions "What is the economic value of a museum that has very low attendance? Are people who will never visit the Museum of Central Finland willing to pay to maintain it?"

\section{THE ECONOMIC VALUE OF THE MUSEUM OF CENTRAL FINLAND}

Museums are faced with two types of demand, namely private and social demand. Social demand is based on the so-called external effects related to benefits for non-users. Frey and Meier (2008) argue that five types of non-user benefits can be distinguished in the literature:

Table 2. The Museum of Central Finland 1978-2006.

\begin{tabular}{|l|c|c|c|c|c|c|}
\hline Year & Man-year & $\begin{array}{c}\text { Costs } \\
\$\end{array}$ & $\begin{array}{c}\text { Wages } \\
\$\end{array}$ & $\begin{array}{c}\text { State subsidies } \\
\$\end{array}$ & $\begin{array}{c}\text { Municipalities } \\
\$\end{array}$ & $\begin{array}{c}\text { Visitors } \\
\text { N }\end{array}$ \\
\hline 2006 & 20 & 1.195 .975 & 681.055 & 363.680 & 707.560 & 20.673 \\
\hline 1998 & 21 & 1.028 .534 & 530.237 & 320.297 & 590.038 & 19.753 \\
\hline 1996 & 23 & 1.130 .000 & 598.000 & 303.000 & 723.000 & 26.280 \\
\hline 1984 & 14 & 320.566 & - & 26.069 & 320.566 & 33.165 \\
\hline 1978 & - & 85.438 & - & 6.164 & 76.946 & 46.019 \\
\hline
\end{tabular}


128 1) option value, 2) existence value, 3) bequest value, 4) prestige value and 5) education value. Option value means the opportunity to use and enjoy the valued object sometime in the future. Existence value derives its utility from knowing that a museum exists. Bequest value means that people benefit from knowing that their relatives and descendants will be able to visit the museum in the future. Prestige value comes from the knowledge that people all over the world value the museum very highly. Education value means that a museum contributes to people's sense of culture and that they value it as a consequence of that.

The author's thesís (Tohmo, 2007) sought to clarify the willingness of local residents aged $18+$ to pay to maintain the Museum of Central Finland and of the factors which affect that willingness. The first aim was to determine the economic value of the Museum of Central Finland using the CV method. The second aim of the study was to utilise a prognostic model to identify the factors involved in willingness-to-pay to maintain the museum. Moreover, the factors characterizing high bids and low bids, respectively, were analysed. Finally, the difference between users (visitors) and non-users was analysed in detail.

The contingent valuation method (CV method) has a long-standing history within environmental economics. The contingent valuation method was first proposed by CiriacyWantrup (1947). The most important landmarks of the CV method have been: 1) the EPA (Environmental Protection Agency) conference in $1984,{ }^{3}$ which aimed at assessing the state of the art of CV studies; 2) the publication by Mitchell \& Carson (1989), which has become the standard reference on contingent valuation; 3) a state-of-the-art study (Carson et al., 1992) in which the contingent valuation method was applied to estimate the lost existence values caused by the running aground of the oil-tanker Exxon Valdez in 1989 on Bligh Reef in Prince William Sound, Alaska; 4) the Exxon symposium (Hausman, 1993); and 5) the NOAA (National Oceanic and Atmospheric Administration) panel report by Arrow et al. (1993) to consider whether CV can produce accurate estimates of non-use values in damage suits. Moisseinen (1997) considers other factors affecting the development of the CV method: 1) environmental problems have given external impetus to the use of $\mathrm{CV}$; 2) the commonly used mean measure is consistent with Pareto efficiency and costbenefit analysis; 3) willingness-to-pay values are more reliable than willingness-to-accept values; 4) legislation in the USA has brought about a practical context for lost non-use values; and 5) the general strategy of assessing the validity of applications by comparing the results with those produced by other valuation methods or studies.

Our study focused on the use of contingent valuation to measure the value of the Museum of Central Finland. We follow the NOAA Panel (Arrow et al., 1993) guidelines for applications of the contingent valuation method. The guidelines for CV surveys concern - among other things - the design of the study and the format used to elicit willingness-to-pay. The principal sources of the biases connected with contingent valuation studies, the conditions that promote their occurrence and the approaches that may be used to minimize their effects (see e.g. Mitchell \& Carson, 1989) are also taken into account. Throsby (2003) points out that the $\mathrm{CV}$ method is not suitable for valuing cultural goods identifiable in relation to the group rather than individuals, such 
as considering the value of the French language or the rock paintings of Kakadu to indigenous Australians.

The CV method has mostly been applied to the valuation of environmental goods and benefits and only occasionally to cultural goods. The bibliography by Carson et al. (1994) lists 1600 studies worldwide on such topics as the environment, health, arts and transportation. The bibliography by Noonan (2002) lists 53 CV studies on the arts and culture. Culturerelated CV studies include Throsby \& Withers, 1983, Morrison \& Westi, 1986 and Bille Hansen, 1996 and 1997. Of these, nationallevel CV studies have been published by Throsby \& Withers (1983) and Morrison and Westi (1986). Only eight studies concerned museums. CV studies on museums include Martin (1994), Mazzanti (2001) and Frey and Pommerehne (1989).

Moisseinen (1997) follows Mitchell and Carson (1989) in classifying methods for estimating values based on a behavioural linkage between change in an amenity and the effects of that change. Methods are categorized, firstly according to whether the data is based on observed behaviour or people's responses to the hypothetical questions. Secondly, methods are classified according to the ability of the method to produce monetary values directly or through indirect techniques. The $\mathrm{CV}$ method is a direct hypothetical method and up to the present continues to be the only method that provides reliable results on the non-use values of non-market items. People who make no active use of a certain item (or never intend to) may nevertheless derive satisfaction from its mere existence. Willingnessto-pay measures how much the consumer is ready to pay for an increase in benefit. Arrow et al. (1993) argue that this existence value is the major element of non-use or passive-use

\section{CONCLUSIONS}

Museums are significant institutions serving multiple purposes. In the economic sense, museums create economic activity in the form of creating jobs and revenues. Furthermore, these jobs and revenues have multiplier effects on the economy. This is the first element in the social demand for museums. The second component consists of the so-called external effects and is based on the benefits to nonusers. Non-user benefits were studied by the author in the case of the Museum of Central Finland.

Willingness-to-pay was investigated with the CV method to examine the Museum of Central Finland and the factors that affect willingness-to-pay among residents of Jyväskylä aged 18+ (Tohmo, 2007). The study obtained many interesting results concerning the valuation of the museum and the factors affecting local residents' willingness-to-pay both for users and non-users. The results showed, firstly, that the residents of Jyväskylä were willing to pay to maintain the museum over and above the amount they were already contributing via taxes. Secondly, with regard to the factors affecting willingness-to-pay, the results showed that visiting art exhibitions positively affected willingness-to-pay to maintain the $\mathrm{Mu}$ seum of Central Finland while attendance at a concert (excluding symphony concerts) negatively affected willingness-to-pay. This is in line with Frey and Meier (2008), who point out that, for example, going to other cultural events such as the theatre or cinema or participating in other leisure activities affects the prices and costs of museums. Moreover, within 
130 the sector, one museum may be an alternative to another museum.

The results also showed that different factors among the high bids compared to low bids explained the respondents' willingness to pay to maintain the Museum of Central Finland. Among the low bids, the motivating influences were more frequently the number of visits made to the museum. Among the high bids, the respondents were willing to pay more if they felt that too little taxpayers' money was directed to the Museum of Central Finland, compared to those who thought the opposite. As a consequence, among the high bids an attitude towards the amount of taxpayers' money set aside for the Central Finland Museum was more frequently cited as the underlying motive for willingness to pay. Finally, the results of the thesis indicate that the museum has non-use value. Many respondents had not visited the museum and did not intend to visit it in the future, yet nevertheless reported willingness to pay for the maintenance of the museum.

\section{NOTES}

1. In the domain of culture, economic research can study the problems of demand and supply and questions related to the allocation of resources and the public support of culture. Matters connected with effectiveness and productivity can also be studied. Johnson and Thomas (1998) suggest areas where research by economists might prove most fruitful. One of these is that estimates of visitors' valuation of their visits through, for example, contingent valuation studies, would be valuable.

2. For the role of the arts in the local economy, see Heilbrun and Gray (2007) The Economics of
Art and Culture.

3. See Cummings et al., 1986

\section{REFERENCES}

Arrow, K., Solow, R., Portney, P. R., Leamer, E. E., Radner, R. \& Schuman, H. (1993). Report of the NOAA Panel on Contingent Valuation.

Bille Hansen, T. (1996). A CV study of the willingness-to-pay for the Royal Theatre in Copenhagen. The Ninth International Conference on Cultural Economics, Boston, May 8-11.

Bille Hansen, T. (1997). The willingness-to-pay for the Royal Theatre in Copenhagen as a public good. Journal of Cultural Economics 21, 1-28.

Carson, R. T., Mitchell, R. C., Hanemann, W. M., Kopp, R. J., Presser, S. \& Ruud, P. A. (1992). A contingent valuation study of lost passive use values resulting from the Exxon Valdez oil spill. A Report to the Attorney General of the State of Alaska. Natural Resource Damage Assessment and Restoration Program, U.S. Department of Interior.

Carson, R. T., Wright, J., Carson, N., Alberini, A. \& Flores (1994). A bibliography of contingent valuation studies and papers. La Jolla, California.

Ciriacy-Wantrup, S. V. (1947). Capital returns from soil-conservation practices. Journal of Farm Economics 29, 1181-1196.

Cummings, R. G., Brookshire, D. S. \& Schulze, W. D. (Eds.) (1986). Valuing environmental goods: An assessment of the contingent valuation method. Rowman \& Allanheld Publishers.

Frey, B. S. \& Meier, S. (2008). The Economics of Museums. In Ginsburgh, V. A. \& Throsby, D. (2008): Handbook of the economics of art and culture. Handbooks in economics 25. Elsevier, North-Holland.

Frey, B. S. \& Pommerehne, W. W. (1989). Muses and markets: Explorations in the economics of the arts. Oxford, Basil Blackwell. 
Goudriaan, R. \& van't Eind, G. J. (1985). To fee or not to fee: Some effects of introducing admission fees in four museums in Rotterdam. In V. L. Owen \& W. S. Hendon (1985): Managerial economics for the arts. Third International Conference on Cultural Economics and Planning April 25-28, 1984, Akron, Ohio. Association for Cultural Economics.

Hausman, J. A. (Ed.) (1993). Contingent valuation, a critical assessment. Elsevier Science Publishers, Netherlands.

Heilbrun, J. \& Gray, C. M. (2007). The Economics of Art and Culture. Cambridge University Press.

ICOM (1986). Dictionary of Museology. International Council of Museums. Budapest.

Johnson, P. \& Thomas, B. (1998). The Economics of Museums: A Research Perspective. Journal of Cultural Economics 22, 73-85.

Khakee, A. (1994). Kulturen i ett ekonomiskt perspektiv. Kultur I Norden 3, 14-22.

Martin, F. (1994). Determining the size of museum subsidies. Journal of Cultural Economics 18, 255270.

Mazzanti, M. (2001). Discrete choice models and valuation experiments. An application to cultural heritage. Universita di Pavia, dipartimento di economia pubblica e territoriale. Societa italiana di economia pubblica working paper, October 5, 2001.

Mitchell, R. C. \& Carson, R. T. (1989). Using surveys to value public goods. The contingent valuation method. Washington DC.

Moisseinen, E. 1997. Contingent valuation: The case of the Saimaa Seal. Joensuun yliopiston yhteiskuntatieteellisiä julkaisuja, N:O 28. University of Joensuu publications in social sciences.

Morrison, W. G. \& Westi, E. G. (1986). Subsidies for the performing arts: Evidence on voter preference. Journal of Behavioral Economics 15, 57-72.

Museum Statistics (1978, 1984, 1996, 1998, 2006). Museotilasto, Museovirasto.
Noonan, D. (2002). Contingent valuation studies in the arts and culture: An annotated bibliography. The Cultural Policy Center, working paper, Chicago.

O'Hagan, J. W. (1995). National museums: To charge or not to charge? Journal of Cultural Economics 19, 33-47.

Throsby, C. D. (2003). Determining the value of cultural goods: How much (or how little) does contingent valuation tell us? Journal of Cultural Economics 27, 275-285.

Throsby, C. D. \& Withers, G. A. (1983). Measuring the demand for the arts as a public good: Theory and empirical results. In W. S. Hendon \& J. L. Shanahan (1983): Economics of Cultural Decisions. Abt. Books, Cambridge.

Tohmo, T. (2007). Regional economic structures in Finland. Analyses of location and regional economic impact. Jyväskylä Studies in Business and Economics 57. University of Jyväskylä. Dissertation.

Tufts, S. \& Milne, S. (1999). Museums - A supplyside perspective. Annals of Tourism Research 3, 613-631.

Vaughan, D. R. \& Booth, P. (1989). The economic importance of tourism and the arts in Merseyside. Journal of Cultural Economics 132, 21-34.

*PhD Timo Tohmo is Assistant Professor at the Faculty of Business and Economics, University of Jyväskylä.

Address: P. O. Box 35,

40014 University of Jyväskylä

E-mail: timo.tohmo@econ.jyu.fi 